\title{
Terör Saldırılarının Turizm Sektörü Üzerindeki Etkileri: Türkiye Öznelinde Ampirik Bir Analiz
}

\author{
The Effects of Terror Attacks on Tourism Sector: \\ An Empirical Analysis in Turkey Example
}

\author{
Necmettin ÇELIK' ${ }^{1}$, Mehmet KARAÇUKA²
}

\begin{abstract}
ÖZET
Küresel ölçekte artan terör olayları iktisadi, politik ve toplumsal bir takım ardıl sorunların da tetiklenmesine sebep olmaktadır. Bu sorunlardan biri turizm destinasyonlarını hedef alan terör saldırılarının turizm talebi üzerinde yarattığı saptırıcı etkilerdir. Önemli bir turizm merkezi olan Türkiye'de artan terör olayları, terörün ve güvensizlik ortamının turizm sektörü üzerindeki muhtemel etkilerinin incelenmesini gerektirmiştir. Bu amaçla, 1992-2011 dönemi kapsamında, OECD ülkelerinden Türkiye'ye yönelik turizm talebinin terör olayları karşısındaki duyarlılığı Sabit Etkiler Panel Veri Yaklaşımıyla incelenmiş ve terör saldırılarının turizm tercihleri üzerinde saptırıcı etki yaratıp yaratmadığı amprik olarak sınanmıştır. Elde edilen bulgular, genel görüşün aksine, terör olaylarının turizm talebi üzerindeki saptırıcı etkilerinin Türkiye öznelinde ve analiz döneminde dikkate değer ölçüde olmadığını göstermektedir. Çalışmanın turizm talebinin belirleyicileri ekseninde güvenlik perspektifini ön plana çıkararak görece yetersiz ampirik literatüre katkı sağladığı söylenebilir.
\end{abstract}

Anahtar Kelimeler: Turizm Sektörü, Terör Saldırıları, OECD, Türkiye.

\section{GiRiş}

Gerek bölgesel; gerekse de küresel düzeyde dramatik bir şekilde artış gösteren terör saldırılarının politik ve diplomatik yansımaları kadar iktisadi yansımları da belirgin bir şekilde ön plana çıkmaktadır. Bu yansımaların başında, özellikle turistleri ve turizm destinasyonlarını hedef alan terör saldırılarının turizm sektörü üzerinde yarattığı yıkıcı etkiler gelmektedir. Çünkü, terörün sıklık ve sertlik derecesiyle ilişkili olmakla birlikte; bir bölgede yaşanan terör olayları turistlerin o bölgeye yönelik tercihleri üzerinde saptırıcı etkliler yaratabilmekte ve turizm sektörünün telafi edilmesi güç hasarlar almasına sebep olabilmektedir. Özellikle, son yıllarda küresel düzeyde artış gösteren ve daha ziyade sivil

\begin{abstract}
Increasing globally terrorist acts have caused several economic, politic and social problems. One of them is that distorting effects of terrorist attacks are targeting tourism destinations on tourism demand. Increasing terrorist acts in Turkey where is the important tourism center have required that investigation for potential effects of terror and insecurity environment on tourism sector. For this purpose, the sensitivity of tourism demand from OECD countries to the Turkey in 1992-2011 against terrorist incidents analyzed by Fixed Effects Panel Data Methodology and the effects of terrorist attacks on tourism preferences investigated empirically. Contrary to popular opinion, the main findings of the model show that distorting effects of terrorist acts on tourism demand aren't remarkable in Turkey. Study contribute to the relatively inadequate empirical literature by emphasising the security perspective as the determinants of tourism demand.
\end{abstract}

Keywords: Tourism Sector, Terror Attacks, OECD, Turkey.

halkı ve kamusal alanları hedef alan terör olaylarının kitleler üzerinde yarattığı korku bu durumun en temel göstergesidir. Nitekim, doğrudan ya da dolaylı olarak sivil vatandaşları hedef alan terör olaylarının toplam içindeki payı 2001 sonrası dönemde \%22,9'dan \%33,4'e yükselmiş ve terörün yarattığı korku algısı tüm düyada belirgin bir şekilde hissedilir hale gelmiştir.' Dolayısıyla, turizm talebinin iktisadi dinamikleri kadar terör saldırıları gibi güvenlik sorunlarının sektör üzerindeki muhtemel etkilerinin de incelenmesi gerekmektedir. Bu sebeple, turizm talebinin temel belirleyicileri ekseninde turizm destinasyonlarını ve turistleri doğrudan ya da dolaylı olarak hedef alan terör saldırılarının irdelenmesi, turizm talebine yönelik daha tutarlı ve kapsamlı analizlerin yapılabilmesi ve 
gerekli önlemlerin efektif bir şekilde alınabilmesi için oldukça önemlidir.

Özellikle gelişmekte olan ülkelerin yapısal sorunlarının çözüme kavuşturulmasında önemli bir döviz kaynağı olan turizm talebinin turist gönderen ve alan ülkelerin bir takım sosyo-iktisadi dinamiklerine bağlı olarak şekillendiği açıktır. Bu sebeple, gelir düzeyi, turizm arz kapasitesi, fiyatlar genel düzeyi gibi iktisadi faktörlerin yanı sıra terör gibi dışsal bir şokun turizm talebi üzerindeki etkilerinin analiz edildiği çalışmada, öncelikle turizmin ekonomideki yeri ön plana çıkarılarak bir anlamda, yabancı turistlere ve turizm destinasyonlarına yönelik terörist saldırıların ardında yatan mantıksal gerekçe ortaya konulmak istenmiştir. Sonrasında, Türkiye öznelinde, terör saldırılarının turizm sektörü üzerindeki etkileri ampirik bir analizle ortaya konularak turizm talebinin terör olayları karşısındaki duyarlıı̆̆ı saptanmıştır. Özellikle ulusal literatürdeki çalışmaların büyük bir kısmının yalnızca teorik düzeyde kaldığı göz önünde bulundurulduğunda, çalışmanın sunduğu ampirik bulgular ve turizm çalışmalarına katacağı farklı perspektif ekseninde literatüre katkı sağlayacağı düşünülebilir.

\section{TURIZM VE TERÖR}

\subsection{Turizm ve Terör îlişsisi}

Önemli bir kümelenme örneği olan turizm sektörünün finans, sağlık, haberleşme ve eğlence gibi birçok sektör için talep yaratıcı etkilere sahip olduğunu söyleyebiliriz. Nitekim; turizm sektörüyle bağlantılı çok sayıda sektörün bulunması, turizmin ileri - geri bağlantıları yüksek bir sektör olduğunu göstermektedir. Bu doğrultuda, turizmin ekonomi üzerindeki etkilerinin çok yönlü olduğunu ve bu etkileri üç farklı düzeyde ayrıştırmamızın mümkün olduğunu söyleyebiliriz. Bunlar, yalnızca turizm sektörü dahilinde yaratılan istihdam ve katma değeri ifade eden "direkt etkisi", endüstriler arası bağlantı olarak da adlandırılabilen ve turizm sektörüyle bağlantılı sektörler arasındaki tedarik zinciri etkisini ifade eden "dolaylı etkisi" ile direkt ve dolaylı olarak elde edilen gelirin harcanmasıyla ortaya çıkan "uyarılmış etkisi"dir (WTTC, 2013). Bu yönüyle turizm harcamaları, çarpan mekanizması ile kendisinden kat kat fazla gelir yaratılmasını sağlamaktadır (Kar, 2004). Yaratılan tüm bu katma değer ve dışsallıkların somut bir sonucu olarak önemli bir istihdam artışı sağlaması da turizmin ekonomi üzerindeki katkılarından bir diğeridir. Bununla birlikte emek yoğun bir hizmet türü olan turizmin kendi bünyesinde yarattığı istihdam artışıını yanı sıra bağlantılı olduğu sektörlerde de istihdam unsuru üzerinde pozitif etkiler yaratacağı göz ardı edilmemelidir. Tüm bu özellikleriyle turizmin özellikle de ülkemiz gibi gelişmekte olan ülkelerin kalkınma süreçlerinde katalizör etkisi taşıdığı söylenebilir.

Illeri-geri bağlantıları neticesinde sahip olduğu çarpan etkisini göz önünde bulundurduğumuzda, bu sektörde ani bir daralma yaşanması halinde, ekonominin genelinde çarpana bağlı olarak daha sert etkiler ortaya çıkabilmektedir (Emsen ve Değer, 2004). Bu durum iktisadi bir takım sorunları tetikleyebilmektedir. Tüm bunların bilincinde olan terörist grupların özellikle siyasi alanda istikrarsızlık ve güvensizlik ortamı yaratmak amacıyla iktisadi ve diplomatik artçılar doğurabilecek olan turizm destinasyonlarına ve turistlere yönelik eylemler içerisinde yer almaları şaşırtıcı değildir. Nitekim; Tablo 1'de gösterilen turistlere yönelik saldırıların temelinde de bu sebepler yatmaktadır. 
Tablo 1: 1990 - 2012 Yıllarında Turistlere Yönelik Düzenlenen Saldırılar

\begin{tabular}{|c|c|c|c|}
\hline Tarih & Yer & Failler & Olay \\
\hline 09.04.1991 & İstanbul & - & $\begin{array}{l}\text { Yunan tur otobüsüne yönelik gerçekleştirilen ve } 35 \text { kişinin } \\
\text { ölümüyle sonuçlanan silahlı saldırı }\end{array}$ \\
\hline 12.09.1991 & lğdır & PKK & $\begin{array}{l}\text { Otomatik silahlı PKK terör örgütü mensuplarının } 2 \text { ABD vatan- } \\
\text { daşını yaklaşık } 3 \text { saat süreyle alıkoyması }\end{array}$ \\
\hline 02.08.1992 & Bitlis & PKK & $\begin{array}{l}\text { Otomatik silahlı PKK terör örgütü mensuplarının } 13 \text { Alman } \\
\text { vatandaşını alıkoyması }\end{array}$ \\
\hline 29.06.1994 & Marmaris & - & İngiliz turist John Kettel'in öldürülmesi \\
\hline 21.04.1995 & İstanbul & - & $\begin{array}{l}\text { Turistik lokasyonda } 1 \text { kişinin ölümüyle sonuçlanan bomba } \\
\text { yüklü bir aracın infilak etmesi }\end{array}$ \\
\hline 21.05.1995 & Alanya & - & $\begin{array}{l}\text { Rus ve Hollandalı } 1 \text { bayan turistin yaralanması ve } 2 \text { bayan turis- } \\
\text { tin ölümüyle sonuçlanan alıkoyma eylemi }\end{array}$ \\
\hline 13.07 .1995 & Siirt & PKK & 1 Japon turistin kaçırılması ve 5 gün süreyle alıkonulması \\
\hline 14.07 .1995 & İstanbul & $\mathrm{SKG}^{2}$ & 31 kişinin 1 gün boyunca alıkonulması eylemi \\
\hline 27.08.1995 & İstanbul & $\mathrm{KIB}^{3}$ & $\begin{array}{l}\text { Turistik bölgede } 2 \text { kişinin ölümü, } 30 \text { kişinin yaralanması ile } \\
\text { sonuçlanan bombalı eylem }\end{array}$ \\
\hline 10.04.1998 & İstanbul & PKK & $\begin{array}{l}\text { Sultanahmet Meydanı'na bomba atılması neticesinde } 2 \text { Hintli, } \\
1 \text { Yeni Zelandalı turistin ve } 6 \text { Türk vatandaşının yaralanması }\end{array}$ \\
\hline 10.09.2001 & Taksim & $\mathrm{DHKP} / \mathrm{C}$ & $\begin{array}{l}1 \text { kadın canlı bombanın kendisini infilak ettirmesi neticesinde } \\
2 \text { polis memurunun hayatını kaybetmesi ve } 11 \text { 'i polis olmak } \\
\text { üzere } 16 \text { kişinin yaralanması }\end{array}$ \\
\hline 10.07.2005 & Çeşme & $\mathrm{TAK}^{4}$ & $\begin{array}{l}\text { Çeşme'de sahil beldesinde meydana gelen ve en az } 20 \text { sivil } \\
\text { vatandaşın yaralanmasıyla sonuçlanan bombalı eylem }\end{array}$ \\
\hline 16.07 .2005 & Kuşadası & - & $\begin{array}{l}5 \text { kişinin ölümü } 13 \text { kişinin yaralanması ile sonuçlanan ve TAK'ın } \\
\text { üstlendiği; fakat doğruluğunun teyit edilemediği otobüse } \\
\text { gizlenen bombanın infilak etmesi }\end{array}$ \\
\hline 24.07 .2005 & İstanbul & - & $\begin{array}{l}\text { Galata Köprüsü altındaki bir restoranda, bomba patlaması } \\
\text { neticesinde } 3 \text { kişinin yaralanması }\end{array}$ \\
\hline 02.08 .2005 & Antalya & - & $\begin{array}{l}4 \text { kişinin yaralanmasıyla sonuçlanan çöp kutusuna yerleştirilm- } \\
\text { iş ses bombasının patlaması }\end{array}$ \\
\hline 06.02 .2012 & Diyarbakır & PKK & $\begin{array}{l}\text { Yolcu otobüsünün durdurulması ve bir İngiliz turistin kaçırıl- } \\
\text { ması }\end{array}$ \\
\hline
\end{tabular}

\subsection{Turizm Talebinin Terör Olaylarına Karşı Duyarlılığını Belirleyen Kriterler}

Turizm talebinin terör olayları karşısındaki duyarlılığı, bazı kriterler çerçevesinde, dönemden döneme ve ülkeden ülkeye farklılıkgöstermektedir. Bu kriterler üçana eksen dahilinde analizedilebilir. Bunlar; "turistlere ve turizm destinasyonlarına yönelik terörist saldırıların boyutu", "terörist saldırıların sıklık derecesi" ve ölüm ve yaralanmayla sonuçlanan saldırıların toplam içindeki payı olarak yorumlanabilecek olan "terörist saldırıların sertlik derecesi"dir. Bu kriterlerin boyutu, saldırıların uluslararası medyada yer bulma sıklığı ve oluşacak tehdit algısı üzerinde belirleyicilik taşımaktadır. Örneğin; büyük yıkımlar ile sonuçlanan terörist saldırıların yoğun olduğu bölgelere yönelik tehdit algısının potansiyel turistlerin tercihlerinde daha büyük sapmalara sebep olacağı söylenebilir.

Küresel Terörizm Veritabanı istatistiklerine göre; bahsi edilen tüm bu kriterler Türkiye için değerlendirilecekolursa;gerek 1970-2012 döneminde kayda alınmış 3016 terörist saldırıdan yalnızca on sekiz tanesinin turistleri ve turizm destinasyonlarını hedef almış olması; gerekse de bu saldırıların tarihsel süreç içerisinde sıklık derecesinin düşük olması ve birçoğunun taciz niteliğinde kalması, turizm talebinin 
terör olayları karşısındaki duyarlıığının çok yüksek olmayacağının göstergesidir. ${ }^{5}$

\section{LITERATÜR ÖZETi}

Terörolaylarının turizm talebiüzerindeki etkilerinin analizine yönelik çalışmaların Türkiye öznelinde daha ziyade teorik düzlemde olduğunu; buna ilişkin ampirik literatürün yetersiz kaldığını görmekteyiz. Ancak; turizm ve terör saldırıları arasındaki nedensellik ilişkisinin uluslararası literatürde geniş bir yer bulduğunu söyleyebiliriz. Örneğin; SantanaGallego, Rossello-Nadal ve Fourie (2016), terörizmin tursitik ziyaretler üzerindeki etkilerini 1995-2013 dönemi ve 171 ülke kapsamında analiz ettikleri çalışmalarında, terörün negatif etkilerine yönelik bulgulara ulaşmışlardır.

Yazdi ve Khanalizadeh (2016) ise, ABD'ye yönelik uluslararası turizm talebinin belirleyicilerini analiz etmek istedikleri çalışmalarında, bir takım kontrol değişkenlerin yanı sıra 9/11 terörist saldırısının etkilerini 2011 yılı için oluşturdukları gölge değişken üzerinden incelemişlerdir. Elde ettikleri bulgular, terör gibi dışşsal bir şoku turizm talebi üzerinde saptırıcı etki yaratabileceği yönündedir.

Benzer bir şekilde, Ahlfeldt, G. M. (2015), özellikle 9/11 terör saldırısı sonrasında yeni boyutlara ulaşan terörizmin turizm sektörü üzerindeki etkilerini analiz etmek istediği çalışmasında, 1993-2005 döneminde Alman turistlerin 82 ülke kapsamındaki seyahatlerini dikkate almıştır. Elde ettiği bulgular, 9/11 saldırısı sonrasında terör olaylarının özellikle Orta Doğu ülkelerine yönelik turist sayılarında belirgin bir azalışa sebep olduğu yönündedir.

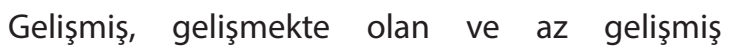
ülkeler gibi çeşitli alt grupları 2002-2011 dönemi kapsamında inceleyen Akıncı ve Yılmaz (2015), gelişmiş ülke gruplarında daha az olmakla birlikte tüm ülke gruplarında, uluslararsı terörizmin turizm üzerinde güçlü bir negatif etki yarattığı bulgusuna ulaşmışlardır.

Sarwar ve Siddiqi (2014) ise, 1995-2011 dönemini dikkate alarak gelişmekte olan ülkeleri politik statüleri açısından özgür ve özgür olmayanlar olarak tasnif ettikleri çalışmalarında, terörizm ve turizm arasındaki ilişkiyi incelemişler ve özellikle demokratik olmayan ülkelerde, gelen turistler üzerinde terörizmin zarar verici etkileri olduğu bulgusuna ulaşmışlardır.

Yap ve Saha (2013) ile Saha ve Yap (2013), politik istikrarsızlık ve terörün turizm üzerindeki etkilerini analiz ettikleri çalışmalarında, 1999-2009 dönemi ve 139 ülkeyi panel veri yaklaşımıyla incelemişlerdir. Elde ettikleri bulgular, politik istikrarsızlıktan daha az olmakla birlikte terörizmin turizm talebi üzerinde negatif etkiler sergilediği yönündedir.

Gazopoulou (2011), terörist saldırıların Yunanistan'ın turizm ve seyahat gelirlerindeki oynaklığı ne derece etkilediğini saptamak istemiştir. 1980-2009 dönemine ait yıllık veriler üzerinden kurguladığı modelde, sanılanın aksine terör olaylarının turizm talebi üzerinde çok düşük etkilere sahip olduğuna yönelik bulgular tespit etmiştir.

Rafael (2008), terörist faaliyetlerin uluslararası turist hareketliliği üzerindeki etkilerini analiz edebilmek amacıyla 2001-2003 döneminde, G-7 ülkelerinden 134 ülkeye (turizm destinasyonuna) yönelik turist hareketliliğini dikkate almıştır. Tahminlediği yatay-kesit verilerine dayalı Çekim (Gravity) Modeli neticesinde, terör olayları ile turist hareketliliği arasında negatif yönlü ve istatistiksel olarak anlamlı etkierin olduğuna dair bulgulara ulaşmıştır. Öte yandan, bu etkilerin gelişmekte olan ülkeler üzerinde gelişmiş ülkelere nazaran daha şiddetli olduğunu saptamıştır.

Thompson (2008), terörizmin gelişmiş ve gelişmekte olan ülkelerin turizm talebi üzerindeki etkilerini ayrıştırabilmek amacıyla 60 ülkeye ait 2003 yılı yatay kesit verilerini kullanarak En Küçük Kareler Yöntemi'ni uyguladığı çalışmasında, gelişmekte olan ülkelerin gelişmiş ülkelere nazaran terör olaylarından daha fazla etkilendiğine yönelik bulgular tespit etmiştir.

Aly ve Strazicich (2002), terör gibi dışsal şokların Mısır ve İsrail'e yönelik turizm talebi üzerindeki etkilerinin kalıcı olup olmadığını analiz etmek istemişlerdir. Mısır için 1955-1997; İsrail için 19711997 dönemini kapsayan yıllık verileri kullanarak yaptıkları çalışmalarında, her iki ülkeye yönelik turizm talebi üzerindeki şokların geçici etkilere sahip olduğunu tespit etmişlerdir.

Fleischer ve Buccola (2002), İsrail öznelinde yaşanan terör olaylarının turistik amaçlı ziyaretçi sayısı üzerindeki etkilerini analiz edebilmek amacıyla Mart 1991 - Aralık 1999 dönemine ait aylık veriler üzerinden İki Aşamada En Küçük Kareler Yöntemi'ni uygulamışlardır. Terör olaylarının turizm talebi üzerindeki saptırıcı etkilerini tespit etmelerinin yanı sıra bu etkilerin terör olaylarının yaşanmasından 
iki ay sonra ortaya çıkmaya başladığı bulgusuna ulaşmışlardır.

Pizam ve Fleischer (2001), İsrail'de 1991-2001 döneminde meydana gelen terör olaylarının sıklık ve sertlik derecelerinin turizm talebi üzerindeki göreceli etkilerini karşılaştırmak amacıyla, aylık verileri kullanarak yaptıkları çalışmalarında, terör olaylarının sertlik derecesinden ziyade sıklık derecesinin daha büyük bir etkiye sahip olduğunu tespit etmişlerdir.

Enders ve Sandler (1991), 1970-1988 döneminde İspanya'da meydana gelen terör olaylarının İspanya'yı ziyaret eden turist sayısı üzerindeki etkilerini analiz etmek istemişlerdir. Aylık veriler üzerinden VAR Modeli'ni tahminledikleri çalışmalarında, terör olayları ile turizm talebi arasında tek yönlü ve negatif bir etkileşimin olduğu sonucuna ulaşmışlardır.

Tüm bu çalışmalardan farklı olarak Mushtaq ve Zaman (2014) ise, politik istikrarsızlık, terörizm ve turizm arasındaki uzun dönemli ilişkiyi analiz etmek istedikleri çalışmalarında, 1995-2012 döneminde Güney Asya Bölgesel İşbirliği Örgütü (SAARC) üyesi dört ülkeyi incelemişlerdir. Genel öngörülerin aksine terörün turizm üzerinde pozitif etkiler sergilediği bulgusuna ulaşmışlar ve bunun turistlerin SAARC Bölgesindeki yüksek riskli bölgelerden daha az riskli bölgelere yönelmesinden kaynaklandığını iddia etmişlerdir.

Türkiye'ye yönelik turizm talebini analiz eden sınırlı sayıdaki çalışmalardan Güvenek ve Alptekin (2015) ise, 1993-2008 döneminde Türkiye'de turistlere yönelik gerçekleştirilen terör saldırılarının ülke turizmini olumsuz etkileyip etkilemediğini analiz ettikleri çalışmalarında, terörist saldırıların turist sayısı üzerimde anlamlı bir etkisinin bulunmadığı sonucuna ulaşmışlardır.

Altay, Ekinci ve Peçe (2013), Türkiye, Mısır ve Suudi Arabistan örnekleminde, terör olaylarının çeşitli iktisadi faktörler üzerindeki etkilerini saptayabilmek adına uyguladıkları Sabit Etkiler Panel Modeli'nde, terör olaylarının turizm talebi üzerinde oldukça yüksek ve negatif bir etkiye sahip olduğuna dair bulgular tespit etmişlerdir.

Emsen ve Değer (2004), Türkiye örneği dahilinde turizm sektörünün terör eylemlerinden etkilenme düzeyini belirlemek amacıyla, 1984-2001 dönemine ait yıllık veriler üzerinden En Küçük Kareler Yöntemi'ni uyguladıkları çalışmalarında, gelir değişkeninin pozitif; terör olaylarınınsa negatif etkilerinin varlığına yönelik bulgular tespit etmişler; fakat reel kurun etkisine dair istatistiksel açıdan anlamlı bulgular saptayamamışlardır. Bununla birlikte, 1991 Körfez Savaşı ve 1999 Depreminin turizm talebi üzerinde etkili olup olmadığını tespit etmek amacıyla, gölge değişken kullanarak genişlettikleri modellerinde, bu şokların turizm talebi üzerinde saptırıcı etkilere sahip olduğunu tespit etmişlerdir.

Drakos ve Kutan (2001), Yunanistan, Türkiye ve İsrail olmak üzere üç Akdeniz ülkesinde meydana gelen terör olaylarının ülkelere yönelik turizm talebi üzerindeki etkilerini analiz etmek istemişlerdir. Bu amaçla, Ocak 1996 - Aralık 1999 dönemine ait aylık veriler üzerinden Görünürde Iliş̧kisiz Regresyon (SUR) Modeli'ni tahminledikleri çalışmalarında, tüm ülkeler için terör olaylarının turizm talebi üzerinde negatif etkilere sahip olduğuna yönelik bulgular tespit etmişlerdir. Ayrıca, yaşanan terör olaylarının ülkelerin turizm sektöründeki piyasa payları üzerinde ikame etkisi yarattığını saptamışlardır.

Bu çalışmaların ötesinde, Türkiye'nin Düzey 2 alt bölgelerine yönelik turizm talebi belirleyicilerini mekansal perspektiften analiz eden Karaçuka ve Çelik (2016), 2001-2012 dönemini Mekansal Hata Rassal Etkiler Panel Modeli üzerinden tahmin etmişlerdir. Elde ettikleri bulgular, Türkiye'nin özellikle Güney Doğu Anadolu Bölgesi'nde yaklaşık otuz yıldır süregelen terörist faaliyetlerin Türkiye'ye yönelik turizm talebi üzerinde herhangi bir saptırıcı etkisinin olmadığı ve turizm sektörünün önemli ölçüde kümelenme örüntüsü sergilediği yönündedir.

\section{YÖNTEM VE ANALIZ}

\subsection{Veri Seti ve Değişkenler}

OECD ülkelerinden ${ }^{6}$ Türkiye'ye yönelik turizm talebinin terör olayları karşısındaki duyarlılığının saptanmaya çalışıldığı bu çalışmada, bir ülkeye yönelik turizm talebinin belirleyicisi konumundaki gelir düzeyi, turizm arz kapasitesi ve efektif döviz kuru gibi iktisadi faktörler de Emsen ve Değer (2004) ve Gazopoulou, H. (2011) gibi çalışmalarla paralel olacak şekilde modele dahil edilmiştir. Bu değişkenlere ilişkin karakteristik bilgiler ve öngörüler Tablo 2'de verilmiştir.

Turizm hizmetine yönelik talebi, klasik talep fonksiyonu olarak dikkate aldığımızda, bu hizmeti almak isteyen potansiyel turistlerin gelir düzeylerinin önemli bir açılklayıcı değişken olacağını; bu değişkenin alacağı katsayının da bir anlamda turizm talebinin gelir esnekliğini yansıtacağını söyleyebiliriz. Turizm 
hizmetinin lüks mal kategorisi içinde yer aldığını göz önünde bulundurursak söz konusu katsayının 1'den büyük değerler alacağını öngörebiliriz.

Çeşitli turizm türlerine ev sahipliği yapan ve yüksek turizm potansiyeline sahip Türkiye'de, turizm arz kapasitesinde yaşanacak artışlar da talep artışı olarak kendisini gösterecektir. Bu sebeple, pozitif yönlü bir iktisadi ilişki beklentilerimiz arasındadır.

Modelimize dahil ettiğimiz döviz kuru, dolaysız kotasyon; yani yabancı para birimi başına ulusal para birimi olarak tanımlandığından döviz kurundaki artış, ulusal para biriminin yabancı para birimi karşısında değersizleşmesi, başka bir ifadeyle \$'ın TL karşısında göreceli olarak değerlenmesi anlamına geleceğinden bu değişkene ilişkin katsayının pozitif değerler alması beklenmektedir.

Son olarak terör gibi dışsal bir şokun bireysel tercihlere dayalı turizm talebi üzerinde bozucu etkiler yaratacağı ve katsayının negatif değerler alacağı beklenmektedir. Ancak, analiz dönemi dahilinde, terör olaylarının etki alanının sıklıkla Türkiye'nin Doğu ve Güneydoğu Anadolu Bölgelerinde gerçekleştiği ve turizm destinasyonlarını hedef alan saldırıların toplam içindeki payının düşük olduğu göz önünde bulundurulduğunda, saptırıcı etkinin çok yüksek olmayacağı da öngörüler arasındadır.

Tablo 2: Analizde Kullanılan Değişkenlerin Karakteristik Bilgileri

\begin{tabular}{|c|c|c|c|c|}
\hline $1992-2011$ & Değișkenler & Açıklama & Tahmini Etki & Kaynak \\
\hline $\begin{array}{l}\text { Bağımlı } \\
\text { Değişken }\end{array}$ & $\frac{\text { Turist Sayısı }}{\text { (LNTUR) }}$ & $\begin{array}{l}\text { OECD ülkelerinden gelen } \\
\text { turist sayısı }\end{array}$ & & TURSAB \\
\hline \multirow{4}{*}{$\begin{array}{l}\text { Açıklayııı } \\
\text { Değişkenler }\end{array}$} & $\frac{\text { Gelir Düzeyi }}{\text { (LNGDP) }}$ & $\begin{array}{l}\text { OECD ülkelerinin kişi başına } \\
\text { düşen milli geliri }\end{array}$ & + & UNDATA \\
\hline & $\frac{\text { Turizm Arz Kapasitesi }}{\text { (LNTESIS) }}$ & $\begin{array}{l}\text { Turizm işletme ve yatırım } \\
\text { belgeli tesis sayısı }\end{array}$ & + & TURSAB \\
\hline & $\frac{\text { Efektif Döviz Kuru }}{\left(\mathrm{KUR}_{\mathrm{TL}}\right)}$ & Dolaysız kotasyon & + & TCMB \\
\hline & $\frac{\text { Terör }}{\text { (LNTER) }}$ & $\begin{array}{l}\text { Türkiye'de meydana gelen } \\
\text { terör olayları }\end{array}$ & - & GTD \\
\hline
\end{tabular}

\subsection{Ekonometrik Model ve Analiz}

OECD Ülkelerinden Türkiye'ye yönelik turizm talebinin terör olayları karşısındaki duyarlılığının saptanabilmesi adına, 1992-2011 dönemini kapsayan yıllık veriler üzerinden sırasıyla Havuzlanmış (Karma), Sabit Etkiler ve Rastsal Etkiler Panel Modelleri'nin tahminlendiği bu çalışmada, yapılan sınama testleri neticesinde değişkenlerimiz arasındaki ilişkiyi en iyi yansıtan modelin Rastsal Etkiler Panel Modeli olduğuna karar verilmiştir. Fakat; bu modelin gerisinde yatan varsayım, kesite özgü hata bileşenleri ile açıklayıcı değişkenlerin ilişkisiz olduğu; başka bir ifadeyle hata terimlerinin çok daha büyük bir ana kütleden rastsal çekildiği yolundadır (Gujarati ve Porter, 2012). Oysa ki; OECD Ülkeleri gibi nispeten ortak özelliklere sahip ülkelerin dikkate alındığı bu çalışmada, bahsi edilen ülkelerin rastsal örneklem olduğunu söylemek güçtür. Bu sebeple; Hausman sınamasına rağmen, Johnston ve Dinardo'nun (1997) her iki model arasında yapılacak seçimin basit bir kuralı olmadığına yönelik uyarılarını da dikkate alarak tüm modellerin sonuçları Tablo 4'de verilmiştir. Modelimizin fonksiyonel formu şu şekilde gösterilebilir:

$$
\begin{aligned}
\text { LNTUR }_{i t} & =\beta_{1 \mathrm{i}}+\beta 2 * \text { LNGDP }_{i t}+\beta 3 * \text { LNTESIS }_{i t}+\beta 4^{*} \\
\text { KURTL }_{i t} & +\beta 5 * \text { LNTER }_{i t}+u_{i t} \\
i & =1,2 \ldots, 30 \text { (Kesit boyutu) } \\
t & =1,2 \ldots, 20 \text { (Zaman boyutu) }
\end{aligned}
$$

Kurguladığımız bu modelin tahminlenmesine geçmeden önce modelimizdeki tüm değişkenlerin durağan olup olmadıklarının sınanması gerekmektedir. Çünkü, durağan olmayan zaman serileri arasında, örneklem çok büyük olduğunda bile, düzmece ilişki varlığını sürdürecek; bu sebeple $\mathrm{R}^{2}$ ve t istatistikleri yanıltıcı olabilecektir (Gujarati ve Porter, 2012). 
Tablo 3: Birim Kök Test Sonuçları

\begin{tabular}{|c|c|c|c|c|c|c|}
\hline & & Levin, Lin\&Chu & Breitung & $\begin{array}{l}\text { Im, P.\& } \\
\text { Shin W }\end{array}$ & ADF & PP \\
\hline \multirow{2}{*}{ LNTUR } & $C$ & -0.70463 & - - - - - & 3.71503 & 23.8363 & 25.5084 \\
\hline & $C+T$ & $-8.03707^{a}$ & $-3.45489^{a}$ & $-5.28137^{a}$ & $133.022^{\mathrm{a}}$ & $136.341^{\mathrm{a}}$ \\
\hline \multirow{2}{*}{ LNGDP } & $C$ & $-1.36752^{\mathrm{b}}$ & - - - - & 3.90190 & 20.9174 & 10.9992 \\
\hline & $C+T$ & -0.21016 & $-2.78965^{a}$ & 0.42474 & 44.4131 & 33.8693 \\
\hline \multirow{2}{*}{ LNTES } & $C$ & 5.34513 & - . - - & $-1.70136^{b}$ & 60.9418 & 13.3191 \\
\hline & $C+\mathrm{T}$ & $-3.30272^{\mathrm{a}}$ & 2.71277 & $-5.86623^{a}$ & $128.083^{a}$ & $19.0491^{\mathrm{a}}$ \\
\hline \multirow{2}{*}{ DLNTES } & $C$ & $-14.1987^{a}$ & - - - - & $-8.87196^{a}$ & $185.708^{a}$ & $79.2947^{\mathrm{a}}$ \\
\hline & $\mathrm{C}+\mathrm{T}$ & $-14.7348^{a}$ & $-9.7441^{a}$ & $-7.63144^{a}$ & $159.088^{a}$ & 61.9972 \\
\hline \multirow{2}{*}{$K U R_{T L}$} & $C$ & $-2.10253^{b}$ & - . - - & 2.94617 & 18.4742 & 12.1893 \\
\hline & $C+T$ & -0.01214 & $-6.44698^{a}$ & 0.60180 & 38.2867 & 19.0631 \\
\hline \multirow{2}{*}{ LNTER } & $C$ & $-7.73713^{a}$ & - - - - & $-7.03169^{a}$ & $149.219^{a}$ & $109.435^{\mathrm{a}}$ \\
\hline & $C+T$ & 1.79248 & 1.80659 & 0.94647 & 34.9253 & 23.6987 \\
\hline \multirow{2}{*}{ DLNTER } & $C$ & 5.07618 & - . - - & $-5.25852^{\mathrm{a}}$ & $116.773^{a}$ & $334.005^{\mathrm{a}}$ \\
\hline & $C+T$ & 7.55609 & -0.33238 & $-4.10995^{a}$ & $100.038^{a}$ & $345.702^{\mathrm{a}}$ \\
\hline \multirow{2}{*}{ DDLNTER } & $C$ & $-1.69770^{b}$ & - - - - & $-8.66713^{a}$ & $181.475^{\mathrm{a}}$ & $2714.33^{\mathrm{a}}$ \\
\hline & $C+T$ & 3.08034 & $-1.91124^{b}$ & $-4.44375^{a}$ & $105.670^{\mathrm{a}}$ & $695.274^{a}$ \\
\hline
\end{tabular}

Not: a, b ve c sırasıyla \%1, \%5 ve \%10 anlamlılık düzeylerini; C ve C+T sırasıyla trendsiz ve trendli değerleri göstermektedir.

Breitung Birim Kök Testi sonuçlarından referansla modelimizin yeni formunu aşağıdaki gibi tanımlayabiliriz: LNTUR $_{\mathrm{it}}=\beta_{\mathrm{i}}+\beta_{2}{ }^{*} \operatorname{LNGDP}_{\mathrm{it}}+\beta_{3}{ }^{*} \mathrm{D}\left(\mathrm{LNTESIS}_{\mathrm{it}}\right)+\beta_{4}{ }^{*} \mathrm{KURTL}_{\mathrm{it}}+\beta_{5}{ }^{*} \mathrm{DD}\left(\mathrm{LNTER}_{\mathrm{it}}\right)+\mathrm{u}_{\mathrm{it}}$

Regresyon analizi neticesinde tahminlenen üç farklı modelin sonuçları Tablo 4'de yer almaktadır. Her ne kadar Hausman Testi, Rastsal Etkiler Modeli'nin geçerli model olarak kabul edilmesi gerektiğini vurgulasa da, örneklemimizdeki kesit verilerin daha büyük bir ana kütleden rastsal çekilmediğine kuvvetle inandığımızdan, Sabit Etkiler Panel Modeli'nin sonuçlarının yorumlanması uygun görülmüştür.

Tablo 4: Regresyon Analizi Sonuçları

Örneklem: 1992 - 2011

\begin{tabular}{|c|c|c|c|}
\hline & Karma Panel Model & Sabit Etkiler & Rastsal Etkiler \\
\hline C & $3.69 *$ & 0.37 & 0.44 \\
\hline LNGDP & $0.73^{* * *}$ & $1.07 * * *$ & $1.07^{* * *}$ \\
\hline D(LNTESIS) & 1.80 & $1.98 * * *$ & $1.97^{* * *}$ \\
\hline $\mathrm{KUR}_{\mathrm{TL}}$ & $0.39^{* * *}$ & $0.25 * * *$ & $0.26^{* * *}$ \\
\hline DD(LNTERÖR) & -0.05 & $-0.06 * * *$ & $-0.06 * * *$ \\
\hline $\begin{array}{c}\text { Kısıtlandırılmış } \\
\text { F Test }\end{array}$ & \multicolumn{2}{|c|}{406.43} & \\
\hline Hausman Test & & \multicolumn{2}{|c|}{0.000} \\
\hline Düzeltilmiş $\mathrm{R}^{2}$ & 0.14 & 0.96 & 0.70 \\
\hline NxT & 540 & 540 & 540 \\
\hline
\end{tabular}

Not: $\left({ }^{*}\right),\left({ }^{* *}\right),\left({ }^{* *}\right)$ sembolleri, sırasıyla $\% 10, \% 5$ ve $\% 1$ anlamlılık düzeylerini göstermektedir. 
Sabit Etkiler Panel Modeli sonuçlarına göre; tüm açıklayıcı değişkenlerin öngörülen etkileri taşıdığı ve istatistiksel olarak anlamlı oldukları görülmektedir. Ülkemize yönelik turizm talebi üzerindeki en yüksek ve pozitif yönlü katsayıya turizm ve yatırım işletme belgeli tesis sayısını ifade eden "turizm arz kapasitesi değişkeninin" sahip olduğu görülmektedir. Bu değişkende meydana gelecek \% 1'lik artışın turizm talebini \% 1,98 oranında arttıracağı söylenebilir. Turist gönderen ülkelerin gelir düzeyini ifade eden ve bir anlamda turizm talebinin gelir esnekliğini yansıtan "gelir değişkenin" 1,07 gibi pozitif ve istatistiksel olarak anlamlı bir katsayıya sahip olması, turizm hizmetinin lüks mal grubu içerisinde yer aldığına yönelik iktisadi literatürle örtüşmektedir. Bununla birlikte, dolaysız kotasyon olarak tanımlanan efektif döviz kuru değişkeninin de çok yüksek olmasa da beklentilerimize uygun bir şekilde pozitif ve istatistiksel olarak anlamlı bir katsayıya sahip olduğu görülmektedir. Bu doğrultuda, ulusal para biriminin döviz karşısında değersizleşmesinin turizm hizmetini göreceli olarak ucuzlatarak turizm talebini arttıracağını söyleyebiliriz.

Temel araştırma konusu olan ve turizm talebinin terör olayları karşısındaki duyarlıı̆ı̆ını yansıtan terör değişkenine ait katsayının "-0,06" gibi çok düşük bir değer aldığını görmekteyiz. Bu durum, Türkiye öznelinde ve analiz dönemi dahilinde, terör olaylarının turizm talebi üzerinde dikkate değer ölçüde saptırıcı bir etkisinin olmadığını göstermektedir. Elde edilen bulgular, Yunanistan öznelindeki Gazopoulou (2011) ile Türkiye öznelindeki Karaçuka ve Çelik (2016), Güvenek ve Alptekin (2015) gibi çalışmaların bulgularıyla paralellik göstermekte; buna karşın negatif işaretli katsayının büyüklüğü açısından Altay, Ekinci ve Peçe (2013) çalışmasıyla farklııı göstermektedir.

\% 1 anlamlılık düzeyinde istatistiksel olarak anlamlı bulunan bu katsayının düşük değerler alması beklentilerimizle çelişmemektedir. Nitekim; istatistiksel olarak elde ettiğimiz bulgular, turizm talebinin terör olayları karşısındaki duyarlıığını belirleyen kriterlerin Türkiye örneğindeki boyutlarıyla örtüşmektedir. Türkiye örneği dahilinde, terör olaylarının turizm talebi üzerinde yıkıcı etkilere sahip olmamasının bir diğer sebebi olarak da terör olaylarının turizm destinasyonlarından uzak bölgelerde yoğunlaşmakta olması gösterilebilir. Nitekim; 2004-2011 döneminde meydana gelen terör olayları ve ülkemize gelen turist sayıları üzerinden Düzey 2 Bölgeleri için oluşturulan ve turizm ile terör değişkenlerinin mekansal örüntüsünü veren Şekil 1 ve 2, terörün özellikle Doğu ve Güney Doğu Anadolu Bölgesi'nde; turizm faaliyetlerinin ise, Batı ve Güney Batı Bölgesi'nde yoğunlaştığını açık bir şekilde göstermektedir.
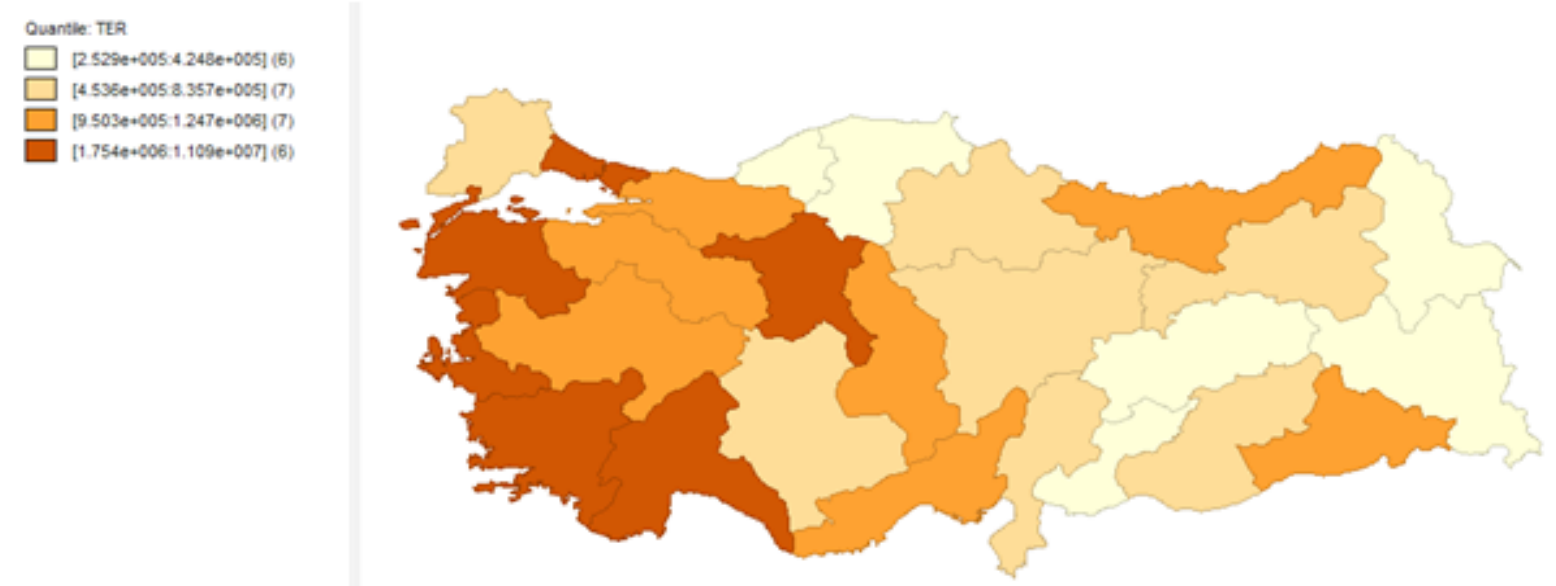

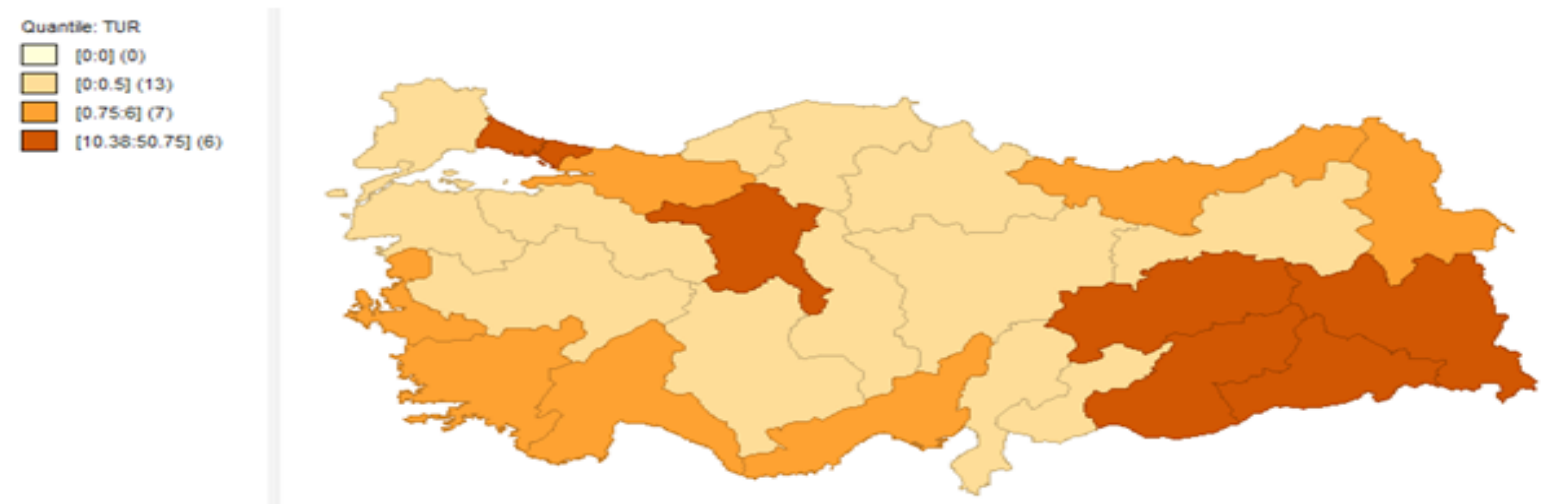

\section{SONUÇ}

1992-2011 döneminde meydana gelen terör olayları ile Türkiye'ye yönelik turizm talebi arasındaki ilişkinin analiz edilmesi amaciyla kurgulanan regresyon modelinde, terör saldırılarının turizm talebi üzerindeki saptırıcı etkilerinin çok yüksek olmadığına yönelik bulgular tespit edilmiştir. Bu durum, Küresel Terörizm Veritabanı'nda kayda alınmış 3016 adet terör saldırısından yalnızca on sekizinin turistleri ve turizm destinasyonlarını hedef almış olması ve Türkiye'deki terörün sertlik ve sıklık derecelerinin düşük olması gibi kriterlerle tutarlılık göstermektedir. Bu doğrultuda, sanılanın aksine terörün Türkiye'ye yönelik turistik tercihler üzerinde belirleyici bir faktör olmadığı söylenebilir. Nitekim, özellikle terör saldırıların turizm destinasyonlarından uzak lokasyonlarda yoğunlaşmasının yıllardır süregelen terörün turizm sektörü üzerindeki yıkıcı etkilerinin hissedilmesini engellediği görülmektedir.

Ancak; terör ve turizm unsurlarının mekansal örüntüsünün belirgin bir şekilde farklı olduğu görülmektedir. Bu sebeple, terör saldırılarının özellikle Doğu ve Güney Doğu Anadolu Bölgesi'nin mevcut turizm potansiyelinin ön plana çıkarılamaması üzerindeki etkilerinin analiz edilmesi; yani turizmterör ilişkisinin bölge düzeyinde de dikkate alınması faydalı olacaktır. Nitekim; terörün şiddet düzeyinin hissedilir olduğu bu bölgelerin turizm potansiyellerinin ortaya çıkarılmasında, bölgede yaşanan terör olaylarının baskılayıcı etkisinin daha ön planda olması oldukça muhtemeldir. Bu sebeple, elde edilen bulgulara çok boyutlu yaklaşılması gerekmektedir. Nitekim; bölgede yaşanan terör olayları ile refah düzeyi arasındaki ilişkinin çift yönlü bir nedensellik sarmalına dönüştüğü ve yapısal sorunların giderilmesinde turizm sektörünün önemli bir dinamik olabileceği unutulmamalıdır. Bu açıdan bakılacak olursa, yaşanan terör olaylarının mevcut turizm merkezlerinin dışındaki bölgelerin turzim potansiyellerinin ön plana çıkarılmasında önemli bir baskılayıcı unsur olduğu göz ardı edilmemelidir.

\section{SON NOTLAR}

${ }^{1}$ https://www.start.umd.edu.tr, Erişim Tarihi: 29 Mayıs 2014.

${ }^{2}$ Sol Kanat Göstericiler

${ }^{3}$ Kürt İslam Birliği Örgütü

${ }^{4}$ Kürdistan Özgürlük Şahinleri

${ }^{5}$ http://www.start.umd.edu/gtd/

6 Veri eksikliği sebebiyle Slovakya, Slovenya ve Estonya analizin dışında tutulmuştur.

\section{KAYNAKÇA}

Ahlfeldt, G. M. (2015) "Terrorism and International Tourism: The Case of Germany", London School of Economics and Political Science, LSE, 1-35.

Akıncı, M. ve Yılmaz, Ö. (2015) “Bir Turizm Krizi Olarak Uluslararası Terörizm: Ülke Grupları İtibariyle Panel Veri Analizi", Kocaeli Ünibversitesi Sosyal Bilimler Dergisi, 30: 51-76.
Aktaş, C. (2005) “Türkiye'nin Turizm Gelirini Etkileyen Değişkenler İçin En Uygun Regresyon Denkleminin Belirlenmesi", Doğuş Üniversitesi Dergisi, 6(2): 163-174.

Aly, H. Y. ve Strazicich, M. C. (2000) "Terrorism and Tourism: Is The Impact Permanent or Transitory?: Time Series Evedince From Some MENA Countries", Ohio State University. 
Altay, H., Ekinci, A. ve Peçe, M.A. (2013) “Ortadoğu'da Terörün Ekonomik Etkileri: Türkiye, Mısır ve Suudi Arabistan Üzerine Bir İnceleme", Dumlupınar Üniversitesi Sosyal Bilimler Dergisi, (37): 267-287.

Drakos, K. ve Kutan, A.M. (2003) "Regional Effects of Terrorism on Tourism: Evidence From Three Mediterranean Countries", Journal of Conflict Resolution, 47(5): 621-641.

Enders, W. ve Sandler, T. (1991) "Causality Between Transnational Terrorism and Tourism: The Case of Spain", Studies in Conflict and Terrorism, 14(1): 49-58.

Emsen, Ö.S. ve Değer, M.K. (2004) "Turizm Üzerine Terörizmin Etkileri: 1984-2001 Türkiye Deneyimi", Akdeniz i.I.B.F. Dergisi, 4(7): 67-83.

Fleischer, A. ve Buccola, S. (2002) "War, Terror, and the Tourism Market in Israel", Applied Economics, 34(11): 1335-1343.

Gazopoulou, H. (2011) "Assessing The Impact of Terrorism on Travel Activity in Grece", Working Papers from Bank of Greece, 127.

Gujarati, D.N. ve Porter, D.C. (2012) Temel Ekonometri, İstanbul: Literatür Yayıncllık.

Güvenek, B. ve Alptekin, V. (2015) "Turistlere Yönelik Terör Saldırılarının Turizme Etkisi: Türkiye Üzerine Ampirik Bir Çalışma", Selçuk Üniversitesi Sosyal Bilimler Meslek Yüksekokulu Dergisi, 17(1): 21-38.

Halıcıoğlu, F. (2004) "An ARDL Model of International Tourist Flows to Turkey", Global Business and Economics Review 2004 Anthology, 614-624.

Johnston, J.ve Dinardo, J. (1997) Econometric Methods, New York, McGraw-Hill.

Kar, M., Zorkirişçi E. ve Yıldıım, M. (2004) "Turizmin Ekonomiye Katkısı Üzerine Ampirik Bir Değerlendirme", Akdeniz i.I.B.F. Dergisi, 4(8): 87-112.

Karagöz, M. (2011)"The Effect of Terrorism on Tourism: Evidence From Turkey", Applied Economics, 43(24): 3349-3354.

Kaya, A. ve Canlı, B. (2013) "Türkiye'ye Yönelik Uluslararası Turizm Talebinin Belirleyenleri: Panel Veri Yaklaşımı", Anadolu Üniversitesi Sosyal Bilimler Dergisi, 13(2): 43-54.

Karaçuka, M. ve Çelik, N. (2016) "Turizm Talebi Belirleyicilerinin Mekansal Perspektiften Değerlendirilmesi: Türkiye İBS 2 Örneği", Finans, Politik \& Ekonomik Yorumlar Dergisi, 52(610): 9 - 20.
Khanalizadeh, B. ve Yazdi, S. K. (2016) "Tourism Demand: A Pane Data Approach", Current Issues in Tourism, 1-14.

Mushtaq, A. ve Zaman, K. (2014) "The Relationship Between Political Instability, Terrorism and Tourism in SAARC Region", Journal of Economic Info, 1(1): 23-40.

Pizam, A. ve Fleischer, A. (2002) "Severity vs. Frequency of Acts of Terrorism: Which Has a Larger Impact on Tourism Demand?", Journal of Travel Research, 40(3): 337-339.

Rafael, L.V. (2008) "Terrorism and International Tourism: New Evidence", Defence and Peace Economics, 19(2): 169-188.

Saha, S. ve Yap, G. (2013) "The Moderation Effects of Political Instability and Terrorism on Tourism Development: A Cross Country Panel Analysis", Journal of Travel Research, 20(10): 1-13.

Santana-Gallego, M., Rossello, J. ve Fourie, J. (2016) "The Effects of Terrorism, Crime and Corruption on Tourism", ERSA Working Paper 595, 1-25.

Sarwar, S. ve Siddiqi, M. W. (2014)"Terrorism or Political Terrorism Vs Tourism: New Evidence from Developing Countries", International Affairs and Global Strategy, 19: 1-9.

Surugiu, C., Leitao, N.C. ve Surugiu, M.R. (2011) "A Panel Data Modelling of Internatinal Tourism Demand: Evidences for Romania", Economic Research, 24(1): 134-145.

Thompson, A.S. (2011) "Terrorism and Tourism in Developed Versus Developing Countries", Tourism Economics, 17(3): 693 - 700.

Yap, G. C. L. ve Saha, S. (2013) “Do Political Instability, Terrorism, and Corruption Have Deterring Effects on Tourism Development Even in the Presence of Unesco Heritage? A Cross Country Panel Estimate", Tourism Analysis, 18: 587-599.

Yavaş, A. ve Aydoğdu, Ö. (2004) "Küresel Krizleri Yönet(eme)mek Turizm ve Terörizm", I. Balıkesir Ulusal Turizm Kongresi.

Yeşiltaş, M., Öztürk, İ. ve Türkmen, F. (2008) "Terör Faaliyetlerinin Turizm Sektörüne Etkilerinin Çözüm Önerileri Perspektifinde Değerlendirilmesi", $A K U$ Sosyal Bilimler Dergisi, 10(1): 175-189.

World Travel and Tourism Council, (2013) "Benchmarking Travel \& Tourism Global Summary: How Does Travel and Tourism Compare to Other Sectors?". 